\title{
Molecular characterization of $G$ and P-types bovine rotavirus strains from Goiás, Brazil: high frequency of mixed P-type infections
}

\author{
Thabata Alessandra Ramos Caruzo ${ }^{1 /+}$, Willia Marta Elsner Diederichsen de Brito ${ }^{2}$, \\ Veridiana Munford³, Maria Lúcia Rácz ${ }^{3}$
}

${ }^{1}$ Departamento de Genética, Evolução e Bioagentes, Instituto de Biologia, Universidade Estadual de Campinas, Campinas, SP, Brasil ${ }^{2}$ Instituto de Patologia Tropical e Saúde Pública, Laboratório de Virologia Animal, Universidade Federal de Goiás, Goiânia, GO, Brasil

${ }^{3}$ Departamento de Microbiologia, Instituto de Ciências Biomédicas, Universidade de São Paulo, São Paulo, SP, Brasil

In this study, 331 samples from calves less than one month old from a dairy herd in the district of Piracanjuba, state of Goiás, Brazil were tested for rotavirus. Thirty-three samples (9.9\%) tested positive for rotavirus. Out of those, 31 were submitted to $G$ and $P$ characterization by reverse transcription followed by semi-nested polymerase chain reaction. Two samples were characterized as G6P[1], three as G10P[11] and five as G6P[11]. The majority of the samples (51.6\%) displayed multiple P genotypes (P-genotype mixtures), including typical human genotypes $P[4]$ and P[6M], suggesting the occurrence of co-infections and genetic reassortment. Also, the detection of human genotypes in bovine samples may be considered evidence of the zoonotic potential of rotaviruses. To our knowledge, this is the first report of such a high frequency of $P$ genotype mixtures in bovine rotavirus samples. It also increases data on $G$ and P rotavirus genotypes circulating in dairy herds in Brazil and can help in the development of more efficient immunization approaches, thereby controlling infection and reducing economical losses.

Key words: bovine rotavirus - genotyping - mixed infections - reassortment - Brazil

Rotaviruses have been recognized as important agents of acute diarrhoea in both humans and animals (Greenberg \& Estes 2009) and are responsible for considerable economical losses worldwide. Members of the Reoviridae family, genus Rotavirus, rotaviruses are classified into seven groups, A-G (Estes \& Kapikian 2007). The virion has a triple-layered protein capsid of $100 \mathrm{~nm}$ in diameter, surrounding a genome composed of 11 segments of double stranded RNA (dsRNA). Each segment encodes six structural and six non-structural proteins (Greenberg \& Estes 2009).

Group A rotaviruses (RV-A) are classified as G and P-genotypes according to two type-specific outer capsid proteins, VP7 (glycoprotein) and VP4 (protease sensitive), respectively. Genotype-specific classification is based on results from reverse transcription followed by polymerase chain reaction (RT-PCR) and nucleotide sequence analysis. Based on molecular differences, at least 23 different G-types and 32 P-types have been described so far ( Hoshino \& Kapikian 2000, Rao et al. 2000, Martella et al. 2007, Ghosh et al. 2008, Greenberg \& Estes 2009, László et al. 2009, Matthijnssens et al. 2009, Schumann et al. 2009, Solberg et al. 2009, Trojnar et al. 2009).

Due to its segmented genome, genetic reassortment may occur when at least two different RV-A strains infect

Financial support: FAPESP (93/01848-8, 99/04575-9), (01/14336-3 to TARC)

+ Corresponding author: thabatacaruzo@yahoo.com.br

Received 2 August 2010

Accepted 15 October 2010 a single cell, resulting in (i) new strains, (ii) characterization of more than one G or P-type in one sample, (iii) introduction of animal rotavirus genes in human rotaviruses (HuRV) populations and vice-versa and (iv) natural $\mathrm{RV}-\mathrm{A}$ reassortants infecting different animal species, as suggested by Dhama et al. (2009) in a recent report of the isolation of $\mathrm{G} 3$ and $\mathrm{G} 5$ bovine rotaviruses (BoRV). Also, because VP4 and VP7 genes independently segregate, many $\mathrm{G}$ and $\mathrm{P}$ combinations can be observed in natural infections (Iturriza-Gomara et al. 2001, Palombo 2002, Leite et al. 2008, Matthijnssens et al. 2008a, Dhama et al. 2009, Martella et al. 2010).

BoRV-A have been classified as G6, G8 or G10 genotypes, associated with either $\mathrm{P}[1], \mathrm{P}[5]$ and/or $\mathrm{P}[11]$ and genotypes G6P[5], G6P[1] and G10P[11] are considered the most common ones. However, genotypes G1, G3, G5, G7, G11, G15 and P[7], P[14], P[17] and P[21] have also been described for BoRV-A samples, but less frequently (Hussein et al. 1993, Fukai et al. 1999, Rao et al. 2000, Okada \& Matsumoto 2002, Ghosh et al. 2008).

\section{SUBJECTS, MATERIALS AND METHODS}

A total of 331 stool samples from calves less than one month old from a dairy herd in the district of Piracanjuba, state of Goiás, Brazil was collected directly from the rectum during November and December of 1994 and 1995. RV-As were detected by enzyme immunoassay for rotavirus and adenovirus (EIARAFiocruz), in accordance with Pereira et al. (1985) and polyacrylamide gel electrophoresis (PAGE) as described by Pereira et al. (1983).

Extraction of dsRNA from $20 \%(\mathrm{w} / \mathrm{v})$ faecal suspensions was performed using Trizol ${ }^{\circledR}$ Reagent (Invitrogen), as described by the manufacturer, and stored at $-20^{\circ} \mathrm{C}$. Molecular characterization of $\mathrm{G}$ and P-types by 
semi-nested multiplex RT-PCR was adapted from Gouvea et al. (1990, 1993, 1994a, b), Gentsch et al. (1992) and Das et al. (1994) and the products were detected after separation by electrophoresis in 1.5\% agarose gel.

Super Script ${ }^{\mathrm{TM}}$ One Step RT-PCR with Platinum ${ }^{\mathbb{R}}$ Taq kit (Life Technologies Co) was used as a secondary approach to genotype some P-type negative samples. For negative G-type samples, Platinum ${ }^{\circledR}$ Taq DNA Polymerase (Life Technologies Co) was used. In both approaches, the reaction was modified to include $1 \mathrm{~h}$ RT at $42^{\circ} \mathrm{C}$ followed by 40 cycles of amplification, as described by Das et al. (1994).

Adapted cell culture strains of simian rotavirus SA11 (P[2]G3), BoRV UK (P[5]G6), B223 (P[11]G10) and NCDV (P[1]G6) and HuRV Wa (P[8]G1), DS-1 $(\mathrm{P}[4] \mathrm{G} 2)$ and ST3 (P[8]G4) were kindly supplied by Dr DR Snodgrass (Moredun Research Institute, Scotland) and used as positive controls. Water was used as a negative control in all reactions.

\section{RESULTS}

A total of $33(9.9 \%)$ samples tested positive for RV-A by EIARA and PAGE. Two samples were not submitted to molecular characterization because of insufficient stool.

From a total of 31 BoRV-A samples, only three could not be completely characterized according to their $\mathrm{G}$ or $\mathrm{P}$ specificities. For the others, $\mathrm{G}$ and P-types and many P-type mixtures, including typical HuRV-A P-types, were characterized (Table).

\section{TABLE}

$\mathrm{G}$ and P-types frequency in bovine stool samples from Piracanjuba, state of Goiás, Brazil, November 1994-December 1995

\begin{tabular}{|c|c|}
\hline Genotypes & n (\%) \\
\hline G6P[1] & $3(9.7)$ \\
\hline G6P[11] & $5(16.2)$ \\
\hline G10P[11] & $4(12.9)$ \\
\hline GnegP[11] & $1(3.2)$ \\
\hline $\mathrm{G} 10 \mathrm{P}[11]\left[6 \mathrm{M}^{a}\right]$ & $5(16.2)$ \\
\hline $\mathrm{G} 6 \mathrm{P}[1][5]\left[6 \mathrm{G}^{b}\right][4][6 \mathrm{M}]$ & $1(3.2)$ \\
\hline G6P[1][5][6G][11][4] & $1(3.2)$ \\
\hline G10P[11][4][6M] & $1(3.2)$ \\
\hline G6P[1][11][6M] & $1(3.2)$ \\
\hline G6P[1][5][11] & $3(9.7)$ \\
\hline G6P[1][5][11][6M] & $3(9.7)$ \\
\hline G6P[5][11][4] [6M] & $1(3.2)$ \\
\hline G6Pneg & $2(6.4)$ \\
\hline Total & $31(100)$ \\
\hline
\end{tabular}

$a$ : human group A rotavirus (RV-A) genotype $\mathrm{P}[6]$, M37-like; $b$ : porcine RV-A genotype $\mathrm{P}[6]$, Gottfried-like; n: number of samples.
Strains showing mixtures of genotypes were submitted to single primer semi-nested RT-PCR to confirm the occurrence of more than one genotype, previously detected by multiplex RT-PCR. This precaution was taken to avoid false positive results that could occur due to primer mismatches during multiplex RT-PCR.

\section{DISCUSSION}

Over the years, many epidemiological studies of BoRV-A have reported G6 and G10 as the most common G-types found in herds around the world. In this study, G6 was the most prevalent genotype, accounting for $64.5 \%$ of all 31 samples and G10 was detected in $32.2 \%$ of them (Table). Similar results were found in Italy (Monini et al. 2008), as the authors described $78.5 \%$ of samples as $\mathrm{G} 6$ and $9.9 \%$ as $\mathrm{G} 10$.

Regarding P-types, results found on this study may be considered very peculiar when compared to P-types most frequently, reported P[11] and P[5]. Despite the fact that $32.2 \%$ of all samples were characterized as $\mathrm{P}[11]$ and $9.7 \%$ as $\mathrm{P}[1]$, P-types mixtures were common in this set of samples, accounting for $51.6 \%$ of it (Table). For comparison, Monini et al. (2008) found no $\mathrm{P}[1]$ in their set of samples and $65.1 \%$ of $\mathrm{P}[11], 25 \%$ of $\mathrm{P}[5]$ and only $2.5 \%$ of P-type mixtures.

As reported before, the most common VP7/VP4 combinations for BoRV-A are G6P[5] (UK-like), G6P[1] (NCDVlike) and G10P[11] (B223-like) (Hussein et al. 1993, Fukai et al. 1999, Rao et al. 2000, Okada \& Matsumoto 2002, Ghosh et al. 2008). In this study, no samples were characterized as G6P[5]. Nevertheless, Garaicoechea et al. (2006) characterized 150 (60\%) BoRV-A collected from beef and dairy herds in Argentina as G6P[5]. More recently, this genotype was found in 38.5\% (10/26) of BoRV-A in Australia, as described by Swiatek et al. (2009). Also, $\mathrm{G} 6 \mathrm{P}[5]$ has been reported as the most prevalent BoRV-A genotype (40\%) in samples collected from herds in the South, Southeast and Central Regions of Brazil between 1996-1999, as described by Alfieri et al. (2004).

In this study, only seven samples displayed the other two typical BoRV-A genotypes: three (9.7\%) samples were characterized as $\mathrm{G} 6 \mathrm{P}[1]$ and four $(12.9 \%)$ as G10P[11]. The frequency of these genotypes is similar to that reported by Alfieri et al. (2004), who also tested Brazilian samples (G6P[1], 12\%, and G10P[11], 16\%). However, these frequencies are much higher than those found in other studies: Reidy et al. (2006), in Ireland, characterized only $1.9 \%$ of their 54 samples as G6P[1] and $1.9 \%$ as G10P[11], and Garaicoechea et al. (2006) found no G6P[1] samples and only 4.4\% G10P[11].

Five (16.2\%) samples were characterized as G6P[11]. Reidy et al. (2006) and Garaicoechea et al. (2006) also described this genotype in their studies, but, again, in lower frequencies $(7.4 \%$ and $4.4 \%$, respectively). These authors also characterized some samples as G10P[5]. All these findings could be a result of co-infection and genetic reassortment and they reinforce the idea that segments displaying VP4 and VP7 genes independently segregate in nature (Iturriza-Gomara et al. 2001, Maunula \& Von Bonsdorff 2002, Matthijnssens et al. 2008a, Greenberg \& Estes 2009). 
A total of 16 samples (51.6\%) displayed P-type mixtures (Table), including HuRV-A typical genotypes (P[4] and $\mathrm{P}[6 \mathrm{M}])$. Many of these strains were also characterized as G6 or G10, thus bringing up once more the idea of genetic reassortment and independent gene segregation during virus replication. Reidy et al. (2006) and Swiatek et al. (2009) also described P genotype mixtures, G6P[5][11], in some samples, but again in lower frequencies $(11 \%$ and $15.4 \%$, respectively) when compared to those found in our study (Table). Also, Brito et al. (2000) characterized two G10P[5] [11] strains (2/11) collected from two dairy herds experiencing a rotavirus outbreak in the Central Region of Brazil.

To our knowledge, this high frequency of $P$ genotype mixtures has not been yet described for BoRV-A and it reaffirms RV-A's reassortment potential among animal strains and also between human and animal strains.

Characterization of typical human rotavirus P-types in bovine faecal samples is supported by Matthijnssens et al. (2008a), who, after sequencing all 11 segments of many RV-A strains, found a great constellation of genes with many different origins. Also, Palombo (2002) states that interspecies transmission of rotavirus is not a rare event and may occur frequently in nature. These $41.9 \%$ bovine samples with typical HuRV-A P-types may result in spreading an RV-A displaying new $\mathrm{G}$ and $\mathrm{P}$ occurrences and combinations from cattle to human. This event can become a public health problem, especially in developing countries, where many children can get infected in remote areas and at country sites (Coluchi et al. 2002, Bányai et al. 2004, 2009, Ramani et al. 2009) and among people who manage herds elsewhere. These new viruses may or may not be infectious at first, but they can circulate in the population and undergo other genetic modifications and subsequent adaptations that may be responsible for diarrhoeal disease among humans. In this case, rotaviruses can be considered a zoonosis, as reviewed by Cook et al. (2004) and Martella et al. (2010).

The occurrence of P[6] Gottfried-like genotype in two samples confirms that cattle and piglet co-infection with typical BoRV-A and porcine rotaviruses-A can occur, as reported over the years (Rácz et al. 2000, Palombo 2002, Parra et al. 2008). Recently, Matthijnssens et al. (2008a) characterized all 11 rotavirus gene segments of many strains, including bovine KJ44 and KJ75. These strains were found to have porcine characteristics in all their gene segments, except for VP3 and VP4, which had bovine characteristics.

Results described in this paper reinforce the idea that rotavirus interspecies transmission, co-infection and genetic reassortment frequently occur in nature and that reassortment could be the main mechanism responsible for evolution and diversity of rotaviruses, as already stated (Iturriza-Gomara et al. 2001, Maunula \& Von Bonsdorff 2002, Ghosh et al. 2008, Matthijnssens et al. 2008a, b, Greenberg $\&$ Estes 2009). Nevertheless, the uncommon results found in this paper will be confirmed by gene sequencing.

This paper also provides new data on G and P-types circulating in dairy herds in Brazil and suggests that constant improvement of herd management and immunization approaches may be crucial for controlling rotavirus infections and reducing economical losses.

\section{REFERENCES}

Alfieri AF, Alfieri AA, Barreiros MAB, Leite JPG, Richtzenhain LJ 2004. $G$ and $P$ genotypes of group A rotavirus strains circulating in calves in Brazil, 1996-1999. Vet. Microbiol 99: 167-173.

Bányai K, Bogdá A, Domonkos G, Kisfali P, Molnár P, Tóth A, Melegh B, Martella V, Gentsch JR, Szucs G 2009. Genetic diversity and zoonotic potential of human rotavirus strains, 2003-2006, Hungary. J Med Virol 81: 362-370.

Bányai K, Gentsch J, Glass RI, Új M, Mihály I, Szucs G 2004. Eightyear survey of human rotavirus strains demonstrates circulation of unusual G and P types in Hungary. J Clin Microbiol 42: 393-397.

Brito WMED, Munford V, Vilaça AM, Caruzo TAR, Rácz ML 2000. Characterization of mixed infections with different strains of bovine rotavirus in an outbreak of diarrhea in dairy herds in Goiás, Brazil. Brazilian J Microbiol 31: 140-145.

Coluchi N, Munford V, Manzur J, Vazquez C, Escobar M, Weber E, Mármol P, Rácz ML 2002. Detection, subgroup specificity and genotype diversity of rotavirus strains in children with acute diarrhea in Paraguay. J Clin Microbiol 40: 1709-1714.

Cook N, Bridger J, Kendall K, Gomara MI, El-Attar L, Gray J 2004. The zoonotic potential of rotavirus. $J$ Infect 48: 289-302.

Das BK, Gentsch JR, Cicirello HG, Woods PA, Gupta A, Ramachandran M, Kumar R, Bhan MK, Glass RI 1994. Characterization of rotavirus strain from newborns in New Delhi, India. J Clin Microbiol 32: 1820-1822.

Dhama K, Chauhan RS, Mahendran M, Malik SVS 2009. Rotavirus diarrhea in bovines and other domestic animals. Vet Res Commun 33: 1-23.

Estes MK, Kapikian AZ 2007. Rotaviruses. In DM Knipe, PM Howley, DE Griffin, RA Lamb, MA Martin, B Roizman, SE Straus, Fields virology, 5th ed., Vol. 2, Lippincott Williams Wolters Kluwer, Philadelphia, p. 1917-1974.

Fukai K, Sakai T, Hirose M, Itou T 1999. Prevalence of calf diarrhea caused by bovine group a rotavirus carrying $\mathrm{G}$ serotype 8 specificity. Vet Microbiol 66: 301-311.

Garaicoechea L, Bok K, Jones LR, Combessies G, Odeón A, Fernandez F, Parreño V 2006. Molecular characterization of bovine rotavirus circulating in beef and dairy herds in Argentina during a 10-year period (1994-2003) Vet Microbiol 118: 1-11.

Gentsch JR, Glass RI, Woods P, Gouvea V, Gorziglia M, Flores J, Bimal KD, Bhan MK 1992. Identification of group A rotavirus gene 4 types by polymerase chain reaction. J Clin Microbiol 30: $1365-1373$.

Ghosh S, Samajdar S, Sinha M, Kobayashi N, Taniguchi K, Naik TN 2008. Molecular characterization of rare bovine group A rotavirus G15P[11] and G15P[21] strains from eastern India: identification of simian SA11-like VP6 genes in G15P[21] strains. Virus Genes: 241-249.

Gouvea V, Glass RI, Woods P, Taniguchi K, Clark HF, Forrester B, Fang Z 1990. Polymerase chain reaction amplification and typing of rotavirus nucleic acid from stool specimens. J Clin Microbiol 28: 276-282.

Gouvea V, Ramidez C, Baoguang L, Santos N, Saif LJ, Clark HF, Hoshino Y 1993. Restriction endonucleases analysis of the VP7 genes of human and animal rotaviruses. $J$ Clin Microbiol 31: 917-923.

Gouvea V, Santos N, Timenetsky MC 1994a. Identification of bovine and porcine rotavirus $\mathrm{G}$ types by PCR. J Clin Microbiol 32: $1338-1340$.

Gouvea V, Santos N, Timenetsky MC 1994b. VP4 typing of bovine and porcine group A rotaviruses by PCR. J Clin Microbiol 32: 1333-1337. 
Greenberg HB, Estes MK 2009. Rotaviruses: from pathogenesis to vaccination. Gastroenterology 136: 1939-1951.

Hoshino Y, Kapikian AZ 2000. Rotavirus serotypes: classification and importance in epidemiology, immunity, and vaccine development. J Health Popul Nutr 18: 5-14.

Hussein HA, Parwani AV, Rosen BI, Lucchelli A, Saif LJ 1993. Detection of rotavirus serotypes G1, G2, G3 and G11 in feces of diarrheic calves by using polymerase chain reaction-derived cDNA probes. J Clin Microbiol 31: 2491-2496.

Iturriza-Gomara M, Isherwood B, Desselberger U, Gray J 2001. Reassortment in vivo: driving force for diversity of human rotavirus strains isolated in the United Kigdom between 1995 and 1999. J Virol 75: 3696-3705.

László B, Nyúl Z, Kisfali P, Deák J, Kovács J, Kónya J, Mészner Z, Molnár P, Pátri L, Schneider F, Tóth A, Melegh B, Iturriza-Gomara M, Gray J, Martella V, Szucs G, Bányai K 2009. First detection of P[6],G9 rotaviruses in Hungary - An imported strain from India? J Travel Med 16: 141-143.

Leite JPG, Carvalho-Costa FA, Linhares AC 2008. Group A rotavirus genotypes and the ongoing Brazilian experience - A Review. Mem Inst Oswaldo Cruz 103: 745-753.

Martella V, Bányai K, Matthijnssens J, Buonavoglia C, Ciarlet M 2010. Zoonotic aspects of rotaviruses. Vet Microbiol 140: 246-255.

Martella V, Ciarlet M, Bányai K, Lorusso E, Arista S, Lavazza A, Pezzotti G, Decaro N, Cavalli A, Lucente MS, Corrente M, Elia G, Camero M, Tempesta M, Buonavoglia C 2007. Identification of group A porcine rotavirus strains bearing a novel VP4 (P) genotype in Italian sweinne herds. J Clin Microbiol 45: 577-580.

Matthijnssens J, Bilcke J, Martella V, Ciarlet M, Bànyai K, Rahman M, Zeller M, Beutels P, Van Damme P, Van Ranst M 2009. Rotavirus disease and vaccination: impact on genotype diversity. Future Microbiol 4: 1303-1313.

Matthijnssens J, Ciarlet M, Heiman E, Arjis I, Delbeke T, McDonald SM, Palombo EA, Iturriza-Gomara M, Maes P, Patton JT, Rahman M, Van Ranst M 2008a. Full genome-based classification of rotaviruses reveals a common origin between human wa-like and porcine rotavirus strains and human DS-1-like and bovine rotavirus strains. J Virol 82: 3204-3219.

Matthijnssens J, Ciarlet M, Rahman M, Attou H, Bányai K, Estes MK, Gentsch JR, Iturriza-Gomara M, Kirkwood CD, Martella V, Mertens PPC, Nakagomi O, Patton JT, Ruggeri FM, Saif LJ, Santos N, Steyer A, Taniguchi K, Desselberger U, Van Ranst M 2008 b. Recommendations for the classification of group A rotaviruses using all 11 genomic RNA segments. Arch Virol 153: 1621-1629.

Maunula L, Von Bonsdorff CH 2002. Frequent reassortments may explain the genetic heterogeneityof rotaviruses: analysis of finnish rotavirus strains. J Virol 76: 11793-11800.

Monini M, Cappuccini F, Battista P, Falcone E, Lavazza A, Ruggeri F M 2008. Molecular characterization of bovine rotavirus strains circulating in northern Italy, 2003-2005. Vet Microbiol 129: 384-389.
Okada N, Matsumoto Y 2002. Bovine rotavirus G and P types and sequence analysis of the VP7 gene of two G8 bovine rotaviruses from Japan. Vet Microbiol 84: 297-305.

Palombo EA 2002. Genetic analysis of Group A rotaviruses: evidence for interspecies transmission of rotavirus genes. Virus Genes 24: 11-20.

Parra GI, Vidales G, Gomez JA, Fernandez FM, Parreño V, Bok K 2008. Phylogenetic analysis of porcine rotavirus in Argentina: increasing diversity of G4 strains and evidence of interspecies transmission. Vet Microbiol 126: 243-250.

Pereira HG, Azeredo RS, Leite JP, Andrade ZP, De Castro L 1985. A combined enzyme immunoassay for rotavirus and adenovirus (EIARA). J Virol Methods 10: 21-28.

Pereira HG, Azeredo RS, Leite JP, Barth OH, Suttmoller F, de Farias V, Vidal MN 1983. Comparison of polyacrilamide gel electrophoresis (PAGE), immunoelectronmicroscopy (IEM) and enzyme immunoassay (EIA) for the rapid diagnosis of rotavirus infection in children. Mem Inst Oswaldo Cruz 78: 483-490.

Rácz ML, Kroeff SS, Munford V, Caruzo TAR, Durigon EL, Hayashi Y, Gouvea V, Palombo EA 2000. Molecular characterization of porcine rotaviruses from the Southern Region of Brazil: characterization of an atypical genotype G(9) strain. J Clin Microbiol 38: 2443-2446.

Ramani S, Iturriza-Gomara M, Jana AK, Kuruvilla KA, Gray JJ, Brown DW, Kang G 2009. Whole genome characterization of reassortant G10P[11] strain (N155) from a neonate with symptomatic rotavirus infection: identification of genes of human and animal rotavirus origin. J Clin Virol 45: 237-244.

Rao CD, Gowda K, Reddy BS 2000. Sequence analysis of VP4 and VP7 genes of nontypeable strains identifies a new pair of outer capsid proteins representing novel $\mathrm{P}$ and $\mathrm{G}$ genotypes in bovine rotaviruses. Virology 276: 104-113.

Reidy N, Lennon G, Fanning S, Power E, O’Shea H 2006. Molecular characterisation and analysis of bovine rotavirus strains circulating in Ireland 2002-2004. Vet Microbiol 117: 242-247.

Schumann T, Hotzel H, Otto P, Johne R 2009. Evidence of interspecies transmission and reassortment among avian group A rotaviruses. Virology 386: 334-343.

Solberg OD, Hasing ME, Trueba G, Eisenberg JN 2009. Characterization of novel VP7, VP4 and VP6 genotypes of a previously untypeable group A rotavirus. Virology 385: 58-67.

Swiatek DL, Palombo EA, Lee A, Coventry MJ, Britz ML, Kirkwood CD 2009. Detection and analysis of bovine rotavirus strains circulating in Australian calves during 2004 and 2005. Vet Microbiol 140: 56-62.

Trojnar E, Otto P, Johne R 2009. The first complete genome sequence of a chicken group A rotavirus indicates independent evolution of mammalian and avian strains. Virology 386 : 325-333. 